\title{
Editorial
}

\section{LA ODONTOLOGÍA COMO PARTE DE LA ESTOMATOLOGÍA}

La enfermedad de Heck es una patología ocasionada por la infección del virus del papiloma humano, mediante sus subtipos 13 y 32. Es más frecuente en niños y adolescentes. Las lesiones aparecen como pápulas rosadas discretas con borde liso en la mucosas labial, la lengua o las encías. No producen dolor, pero si llaman la atención del interlocutor del paciente (como vemos en la foto de la portada) y puede ser un obstáculo para el desempeño social del niño, afectando su autoestima, calidad de vida y sus oportunidades en la vida. La Estomatología a diferencia de la Odontología, se ocupa de ver más allá de los dientes, tiene como misión, resolver las necesidades de atención en las lesiones de los tejidos dentales, el periodonto, la oclusión, problemas médicos asociados a la boca, problemas quirúrgicos de la misma y los problemas sociales que se relacionan con las patologías de la cavidad bucal.

La Universidad Católica de Cuenca en permanente contacto con sus graduados, recibe información epidemiológica en salud bucal de distintos lugares, donde son asignados nuestros egresados, en este caso en la comunidad de Taisha se han detectado una gran cantidad de niños con esta patología, es por ese motivo, que en convenio con la Universidad de Cuenca, se realizaron una serie de investigaciones de las cuales en este número se presenta un estudio epidemiológico, producto de los exámenes bucales que se desarrollaron en el servicio rural de uno de nuestros egresados.La Epidemiología Estomatológica es un buen espacio para ejercer abogacía, sobre todo en casos como estos, para ser la voz de los sin voz y para poner en evidencia lo que no se ve. La Estomatología a diferencia de la Odontología, va más allá, epistemológicamente es integradora, holística, crítica, socialmente comprometida y transformadora de la realidad en beneficio de la comunidad.

Dr. Ebingen Villavicencio Caparó Director de la Revista 